DOI: https://doi.org/10.47405/mjssh.v5i1.339

\begin{tabular}{|c|c|}
\hline 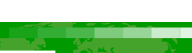 & Malaysian Journal of Social Sciences and Humanities (MJSSH) \\
\hline Malaysian Journal of & Volume 5, Issue 1, January 2020 \\
\hline (MJ . SSH) & e-ISSN : 2504-8562 \\
\hline & $\begin{array}{c}\text { Journal home page: } \\
\text { www.msocialsciences.com }\end{array}$ \\
\hline
\end{tabular}

\title{
An Overview of the History and Development of Applied Linguistics
}

\author{
Mohamed AbdAlla AbdAlgane Mohammed1 \\ 1Department of English Language and Translation, College of Science and Arts-Arrass, Qassim University, Saudi Arabia
}

Correspondence: Mohamed AbdAlla AbdAlgane Mohammed (dr.mohammed_saleem@hotmail.com)

\begin{abstract}
This study is conducted to highlight the brief history of applied linguistics, its development over the years and the work of a few people who have contributed a lot to the development of applied linguistics (AL). Many people have defined or described applied linguistics and some of their definitions will also be presented. These definitions will give you an idea of what applied linguistics entails and the various areas of language endeavor it covers. The main objective of this study is to familiarize EFL learners with the background and nature of the concept of applied linguistics, i.e. giving various definitions of applied linguistics as well as describing how applied linguistics became a discipline. The study adopts the descriptive methodology.
\end{abstract}

Keywords: stapplied linguistics, second language acquisition, language assessment and testing, language policy and planning, lexicography, multilingualism, corpus linguistics

\section{Introduction}

Scholars who have worked in applied linguistics have noted that it often deals with solving or at least ameliorating social problems involving language. Applied Linguistics (AL) answers questions such as; how can we teach language better? What type of individual differences do we have in language learning? What are the social influences that affect language learning? How can we write a valid language examination? How can we best advise Ministry of Education officials, curriculum planners and other stake holders in the Education Ministry on the content of a language curriculum for various groups of people and communities? In short, applied linguistics is interested mainly in language problems. All the areas mentioned above and some other relevant issues will be discussed in this study.

\section{What is Applied Linguistics (AL)?}

As of 1980, broad agreement was achieved among the major practitioners in the field that applied linguistics: (1) was interdisciplinary, drawing on a multitude of disciplines including psychology, sociology, and pedagogy as well as theoretical linguistics; (2) was not limited to language teaching but included a broad range of fields including lexicography, stylistics, speech pathology, translation, language policy, and planning among others; (3) performed a mediating function between theory and practice (Buckingham and Eskey 1980: 2-3). To these three characteristics, we should add that applied linguistics is "problem-based" (Corder 1973: 10) and brings linguistic insight and analysis to bear on practical issues of language use "situated in time, place, society, and culture" (Sridhar 1993: 7). 
So many EFL learners might have probably taken some courses in psycholinguistics, sociolinguistics, multilingualism and some others where the word 'linguistics' or 'applied' have been mentioned. In this study, a clarification of how some of these courses are related to language will be made. Some of the questions that people ask are:

i. What kind of language should be the language of instruction in schools?

ii. What are the procedures for the choice of a language where there are many languages?

iii. How can we have valid language tests?

These and many more are questions that arise frequently that have to be answered by language specialists. Our knowledge of applied linguistics will help us to answer some of these questions. Many people have tried to define or describe what applied linguistic is, below are some of them:

Brumfit (1977:93) opines that: AL is the theoretical and empirical investigation of real world problems in which language is a central issue. Grabe (2000:9) proposes that: The focus of AL is on trying to resolve language based problems that people encounter in the real world, whether they be learners, teachers, supervisors, academics, lawyers, service providers, those who need social services, test makers, policy developers, dictionary makers, translators, or a whole range of clients.

Grabe notes that distinguishing between what linguistics and AL are concerned with is to distinguish between theory and practice. According to Schmitt and Celce-Murcia (2002:1) AL uses what we know about (a) language (b) how it is learned and (c) how it is used in order to achieve some purpose or solve some problems in the real world.

Schmitt and Celce-Murcia note that traditionally, the primary concerns of AL have been second language acquisition theory, second language pedagogy and the interface between the two.

Davis and Elder (2006:11) note the following about AL: AL is, in our view, a coherent activity which theorizes through speculative and empirical investigations real world problems in which language is a central issue.

\section{History of Applied Linguistics}

The term applied linguistics which refers to the application of linguistics to the study and improvement of language teaching, language learning, language planning, management of language defects, communication between groups, lexicography, translation etc. owes its origin to US language-teaching programs during and after the second world war. According to Grabe (2002), (please see complete online reference at the end of the unit) it was largely based on Leonard Bloomfield's outline guide for the practical study of Foreign Languages (1942), which was said to be influenced by the early European advocates of the direct method, in particular, Henry Sweet.

The history of applied linguistics can be discussed in different countries as noted by Grabe (2002) in the next paragraph.

In America, in 1948, a conference was organized by Charles C. Fries, supported, among others, by Kenneth L. Pike and W. Freeman Twaddell at the University of Michigan to disseminate information about work at Fries English Language Institute (founded 1941). At that conference, a quarterly journal of applied linguistics (titled- Language Learning) was started.

In Britain as well, a school of Applied Linguistics was established by J.C. Cartford at the University of Edinburgh in 1956 and the center for AL was set up in Washington, DC, under Charles Ferguson in1959. It has been noted that similar institutes have been set up in various parts of the world. Grabe noted that national associations of applied linguists came together in 1964 to form the Association International de la Linguistique Appliquée (AILA) This association holds a four yearly international congress with published proceedings. 
Davies and Elder (2006:6) commented on the symposium held at the American Association of Applied Linguistics (AAAL) in St Louis in the year 2001 where the history of applied linguistics was considered in four different countries. Angelis (2001) discussing the USA proposed a four-fold division of the history since the 1920s. The history was summarized thus:

i. $\quad$ AL in North America does have identifiable roots in linguistics

ii. While North American AL has evolved over time in its orientation and scope, so has North American linguistics

iii. A significant amount of work directed to real world issues involving language can be attributed to leading North American linguists

iv. Much of what can now be seen as ground breaking applied linguistics type activity was carried out prior to the formal appearance of applied linguistics.

There was a gradual move away from the central focus on linguistics. Angelis notes that until the 1990 s, there were a lot of language activities without much reference to linguistics. It was much later that scholars saw to need to link all these language activities to linguistics in terms of their applications.

McNamara (2001) points to a different tradition for Australian applied linguistics in contrast to the ones for UK and US. To McNamara, Australian applied linguistics made AL of modern languages its target of immigrants rather than English. The application of linguistics to the development of teaching materials and writing systems for aboriginal languages was also focused on.

The Australia tradition of AL shows a strong influence of continental Europe and of USA rather than of Britain. English came in the context of mother tongue teaching and teaching of English to immigrants- English as a Second Language (ESL). The English as a Foreign Language (EFL) British tradition got to Australia in the 1980's. Scholars have noted that the important thing about AL in Australia is its concern for language in education, both with regard to new migrant languages and literacy in English.

The British Association of Applied Linguistics (BAAL) was formally established in 1967 with the aim of advancing education, fostering and promoting by any lawful charitable means, the study of language use, language acquisition and language teaching and the fostering of interdisciplinary collaboration in this study (BAAL, 1994). Davies (2001) notes that the British tradition represented a deliberate attempt to establish a distinctive applied linguistics.

Davies (2001) notes that, it was taken for granted in the 1960s and 70s that AL was about language teaching. Over the last 30 years, it became clear that those studying English language teaching had already studied aspects of linguistics. Lewis (2001:19) notes that AL is trying to resolve languagebased problems that people encounter in the real world; to Davis and Elder (2006:9), AL has grown quickly and it is flourishing with academic positions, academic departments, international journals and an international association.

Davis and Elder (2006:9) commented on Widdowson's distinction between Linguistics Applied (LA) and Applied Linguistics (AL) thus:

The differences between these modes of intervention is that in the case of linguistics applied, the assumption is that the problem can be reformulated by the direct and unilateral application of concepts and terms deriving from linguistic enquiry itself. That is to say, language problems are amenable to linguistic solutions. In the case of applied linguistics, intervention is crucially a matter of mediation...applied linguistics...has to relate and reconcile different representations of reality, including that of linguistics without excluding others (Widdowson, 2000, p.5).

Davis and Elder (2006:9) note that the 'linguistic applied' view derives from the coming together of two traditions; one, the European tradition which was exported to the USA through scholars such as Roman Jacobson and the North American tradition of linguistic anthropological field work which required the intensive use of non-literate informants and the linguistic description of indigenous languages for cultural analysis. 
Scholars such as Bloomfield (1933) and Robins thought that if a teacher understands the use of linguistics as a scientific method in language presentation, his/her work will be easy. Davis and Elder (2006) believe that AL looks outwards beyond language in an attempt to explain and solve social problems while linguistics applied looks inward not to solve language problems in the real world, but to explicate and test theories about language itself. To them, this means that LA uses language data to develop our linguistic knowledge about language while AL studies a language problem with the intention of correcting them (2006:09).

\section{Some Subfields of Applied Linguistics}

Kramsch. C. (2000:316) cites in Davies, A. (1999) that the field of AL includes, besides L1and L2 acquisition and the SLA-related fields mentioned previously, such areas of research as: communication in the professions, communication disorders, language and the media, language and the law, language policy and planning, translation and interpretation, language and technology, stylistics and rhetoric, literacy, discourse and conversational analysis, and sign language re-search. What binds these rather disparate areas of research under the rubric Applied Linguistics is the focus on the relationship between psycho- and sociolinguistic theory on the one hand and social practice on the other, as they relate to the acquisition and use of language in various contexts.

Below are the commonly regarded subfields of applied linguistics as noted Grabe (2002).

\section{Second Language Acquisition}

Second language Acquisition theory deals with the range of variables- in particular, age of immersion, quantity of input etc which may interactively determine the level of ultimate attainment.

\section{Language Assessment and Testing}

Language Assessment plays a gate-keeping role in terms of the functions they serve for institutions and the corresponding preparedness of institutions to invest in their development and validation. It has always involved the development and implementation of frameworks for describing student's progress in language learning over time.

\section{Language Policy and Planning}

The practical nature of language planning deals with the analysis of policy making in contexts where language is a part. Language problems always arise, which could involve rival interest reflecting relations among ethnic, political, social, and bureaucratic and class groupings. Language policy and planning research then draws on knowledge far beyond linguistics to solve such problems where necessary.

\section{Lexicography}

Lexicography is important and an integral part of applied linguistics in second/foreign language learning and teaching at all ages and levels of education. It is concerned with the writing and study of dictionaries for first/second/foreign language education. It also involves mono- bi- and multilingual works and general children's school, college, and specialized technical dictionaries.

\section{Multilingualism}

This is the use of more than two languages within a speech community. Applied linguistics deals with the sociological, psychological, attending problems etc. and the implications of these languages on the speech community. 


\section{Corpus Linguistics}

This is aimed at improving language description and theory and Stubbs (2006) notes that the task of applied linguistics is to assess the relevance of the language description to practical applications. Corpus data are essentially for accuracy in the description of language use and have shown how lexis, grammar and semantics interact.

Some of the supporting disciplines which you must have been introduced to are:
i. Psycholinguistics
ii. Education
iii. Sociolinguistics
iv. English studies
v. Discourse studies

Some other newly introduced ones are in the area of forensic linguistics (language and the law) and Computer Assisted Language Learning (CALL). You do not have to be scared about all these disciplines. It only shows that AL is a growing discipline and has a lot of other supporting disciplines. We will go through some of these while some other courses will take care of some of the other disciplines. In going through them, we will explain how each of the ones discussed relate to applied linguistics.

\section{On the Interdisciplinary Nature of AL and Relevance to Language Teaching}

$\mathrm{AL}$ is a branch of linguistics which is concerned with practical applications of language studies with particular emphasis on the communicative function of the language, and including such professional practices as lexicography, terminology, general or technical translation, language teaching (general, specialized language, mother tongue or second language), writing, interpretation, and computer processing of language. This shows the interdisciplinary nature of AL and the fact that it can be applied to any area of language study. Douglas L. Ride out in his comment on the book Applied Linguistics by Cook (2003), notes that: at its inception in the late 1950s, AL was principally concerned with language teaching especially second/foreign language teaching which became almost synonymous but over time the field grew and expanded to include other fields unrelated to second/foreign language teaching such as language policy and planning, forensic linguistics, clinical linguistics, critical discourse analysis, translation and interpretation and lexicography.

Douglas noted that despite all these latest inclusion, the close association with second/foreign language still stands and that is why most introductory books about AL still devote a large amount of space to second/foreign language teaching. This shows that many other new disciplines may still be added as time goes on. AL is rich and therefore needs to be given a lot of attention.

\section{Conclusion}

This study shed the light on some of the several definitions of applied linguistics made by the various scholars. In addition, it also clarified the mutual relationship between applied linguistics and the other branches of linguistics. A historical background of applied linguistics is given in order to elucidate and acquaint EFL learners with the concept of applied linguistics.

\section{References}

Angelis, P. (2001). The Roots of Applied Linguistics in North America. Colloquium on the Roots of Applied Linguistics in Different Contexts. St Louis: AAAL. Applied Linguistics, 21(1), pp.3-25.

Bloomfield, L. (1933). Language. London: Allen and Unwin. 
Brumfit, C. (1977). How Applied Linguistics is the same as any other Science. International Journal of Applied Linguistics, 7(1), pp.86-94.

Buckingham, T. and Eskey, D. E. (1980). Toward a definition of applied linguistics. In R. Kaplan (ed.), On the Scope of Applied Linguistics (pp. 1-3). Rowley, MA: Newbury.

Corder, S. P. (1973). Introducing Applied Linguistics. Harmondsworth: Penguin.

Davies, A. \& Elder, C. (2006). The Handbook of Applied Linguistics. Blackwell Publishing Ltd.

Davies, A. (1999). An introduction to applied linguistics: From practice to theory. Edinburgh, Scotland: Edinburgh University Press.

Davies, A. (2001). British Applied Linguistics. Colloquium on the Roots of Applied Linguistics in Different Contexts. St Louis: AAAL.

Grabe, W. (2002). Applied Linguistics: An Emerging Discipline for the Twenty-First Century. In: B. Kapla (Ed.). Oxford Handbook of Applied Linguistics. Oxford University Press.

Grabe, W. (Ed.). (2000). Applied Linguistics as an Emerging Discipline. Annual Review of Applied Linguistics 2.

Kramsch. C. (2000). Second Language Acquisition, Applied Linguistics, and the Teaching of Foreign Languages, The Modern Language Journal.

Lewis, M. (2001). Looking Ahead in Applied Linguistics. Applied Linguistics Association of Australia Newsletter, New Series 44, pp.18-19.

McNamara, T. (2001). The Roots of Applied Linguistics in Australia. Colloquium on the Roots of Applied Linguistics in Different Contexts. St Louis: AAAL. Oxford: Blackwell Publishing Ltd.

Schmitt, N. \& Celce - Murcia, M. (2002). An Overview of Applied Linguistics. In: N. Schmitt. (Ed.). An Introduction to Applied Linguistics. London: Arnold, pp. 1-16.

Sridhar, S. N. (1993). What are applied linguistics? International Journal of Applied Linguistics,

Widdowson, H. (2000). "On the Limitations of Linguistics Applied." 